\title{
Suveræne livsytringer og kredsende tanker og følelser - en kritisk udfoldelse af deres karakteristika
}

\author{
Løgstrups ontologiske differens $\mathrm{II}^{1}$ \\ Post.doc., ph.d. \\ Bjørn Rabjerg
}

\begin{abstract}
The "sovereign expressions of life" and the "encircling thoughts and emotions" are phenomena at the core of K.E. Løgstrup's metaphysics and ethics. However, their respective characteristics have not been fully developed until now. In this article these characteristics are examined through a systematic analysis of both types of phenomena in which their differences are exposed. They are both spontaneous, but the encircling thoughts and emotions are found to be our own, self-containing, destructive and reactive thoughts and emotions - whereas the sovereign expressions of life are created and given, definitive, consummated, sovereign, unconditioned, identity creating and anonymous possibilities within interdependent life; as such they possess the power to release us from the confinement of our own thoughts and emotions.
\end{abstract}

Key Words: Sovereign expressions of life - Encircling thoughts and emotions - Ontology - Anthropology - Metaphysics - Løgstrup - Kierkegaard.

Den ontologiske differens: Suveræne livsytringer og kredsende tanker og følelser

Den absolutte modsætning eller ontologiske differens mellem de suveræne livsytringer og de kredsende tanker og følelser udgør en fundamental spænding i Løgstrups tænkning. Med udtrykket ontologisk differens peges på den afgørende, ontologiske forskel mellem menneskelivet og mennesket(s) selv. Spændingen mellem skabelse og synd, mellem tilværelsens skabte ontologiske grundlag (dens godhed) på den ene side og menneskets selviske modstand herimod (menneskets

1. I denne artikel analyseres de karakteristika, der kendetegner hhv. de suveræne livsytringer og de kredsende tanker og følelser. Vedrørende etableringen af modsætningen mellem disse, Løgstrups ontologiske differens, henvises til Bjørn Rabjerg, "Suveræne livsytringer og kredsende tanker og følelser - en kritisk begrebsudvikling”, DTT 77 (2014), 178-196. Nærværende artikel bygger således videre på den forudgående begrebsudvikling. 
ondskab) på den anden side, strækker sig tilbage til den tidligste del af Løgstrups forfatterskab. Grundtanken er, at tilværelsen er skabt og værdifuld, men at den gennem mennesket trivialiseres. Den mister sin glans i den trivialiserende omgang eller eksistens, hvori vi i kraft af vores sind og dets indretning udrydder eller nedbryder denne forståelse, så vi kun har blik for os selv og vort eget: "Vi har altsaa ikke blot glemt, at vi lever i Guds Skabning, men vi har helt udryddet Forstaaelsen deraf". ${ }^{2}$ Vores selvkredsen og indkrogethed forhindrer os $i$ at være åbne ud mod den skabte tilværelse, vi lever i:

Hvis vi kunne fatte det forunderlige i det, at vi kan høre - og at vi kan høre toner! Hvis vi var så åbne, så rent modtagende, at vi kunne opfatte al den skønhed og forunderlighed, der ligger i tonen - så ville vi glemme os selv for tonens salighed; vi ville hørende kun være hørende. (...) Hvis vi kunne opleve det forunderlige i det, at vi kan se - og at vi kan se farver og former! (...) så ville vi seende kun være seende d.v.s. kun modtagende (...). Hvis vi kunne fatte sprogets forunderlighed! At vi ved sproget i samtalen får givet mennesket som medmenneske, så fællesskabet opstår. Hvis vi virkelig kunne modtage medmennesket $\mathrm{i}$ samtalens ord, så ville vi i modtagelsen glemme os selv af undren og glæde over, at medmennesket gives os i sprogets fællesskaber. Hvad er det at være skabt? Det er at kunne modtage; vi kunne også sige, at det at være skabt, det er at være åben - åben ved øjnene, åbne ved hørelsen, åbne ved forståelsen i ordet. ${ }^{3}$

Konjunktiven er afgørende, for den viser, at denne åbenhed hos den unge Løgstrup er utilgængelig for os. At tilværelsen rummer en underfuld skabthed ved han kun fra forkyndelsen, da kendskabet til det er nedbrudt i vort faktiske liv. Synden sætter her ikke kun en absolut etisk grænse for menneskets formån, men også en erkendelsesmassig. Først i revisionen af Løgstrups disputats finder vi den lempelse af syndens erkendelsesmæssige betydning, som leder ham på sporet af, at tilværelsens godhed fuldbyrder sig, så erkendelsen af dette er tilgængelig for menneskets fornuft - uden at dette dog på nogen måde indebærer en lempelse af syndens radikalitet på etikkens område.

Denne spænding mellem det skabte, bærende og åbnende hhv. det selvlavede, nedbrydende og indesluttende fører i $1966^{4}$ til formulerin-

2. K.E. Løgstrup, “Guds Skabning”, Menighedsbladet 20 (1938), 451-454 (451).

3. K.E. Løgstrup, "At være skabt", Pradikener fra Sandager-Holevad, red. Elsebeth Diderichsen \& Ole Jensen (København: Gyldendal 1995), 76-79 (76f).

4. K.E. Løgstrup, "Sartres og Kierkegaards skildring af den dæmoniske indesluttethed”, Vindrosen 13 (1966), 28-42. Artiklen kommer senere med små ændringer til at udgøre kapitel IV i tredje del af Opgør med Kierkegaard. 
gen af begreberne suverane livsytringer og kredsende tanker og folelser, og i det følgende vil de blive bestemt nærmere.

\section{De kredsende tanker og følelser}

I artiklen fra 1966 kritiserer Løgstrup ikke kun Kierkegaard og Sartre for helt at overse de suveræne livsytringer (hvad der ofte betones), men også for, at de kun delvis har øje for de kredsende tanker og følelser - altså at de ikke i tilstrækkelig grad har blik for tilværelsens skyggesider (hvad der ofte overses). At de suveræne livsytringer er blevet betonet skyldes utvivlsomt, at de er kernen i Løgstrups skabelsesteologiske projekt, og at det var dette, der mødte modstand. Skabelsestanken og dermed de suveræne livsytringer udgjorde Løgstrups teologiske front. ${ }^{5}$ Når det imidlertid stort set er blevet overset, at Løgstrup også rettede en kritik mod Kierkegaard og Sartre for, at de overså en væsentlig del af menneskets indesluttethed, skyldes det formentlig hovedsageligt to forhold: (1) Løgstrups nye front lå ikke her, men ved livsytringerne (det var ikke i spørgsmålet om synden og dermed menneskets ondskab, at Løstrup mødte modstand eller ville markere sig), og (2) som følge heraf fylder denne pointe meget lidt i Løgstrups forfatterskab. Et vigtigt sted finder vi imidlertid i form af et afsnit, der blev udeladt i Opgør med Kierkegaard:

For at vende tilbage til Kierkegaard, har da ikke han, om nogen, analyseret de tvungne eller kredsende tanke- og følelsesbevægelser? Jo, nok, men kun når der er gået uendelighedens bevægelse i dem, kun når de har fået religiøst format. Indesluttetheden, når den ikke er dæmonisk, når bevægelsen i den bare er endelig som i fornærmelsen, skinsygen og misundelsen, interesserede ham ikke (Løgstrup 1966, 36). ${ }^{6}$

5. Løgstrup var inden introduktionen af de suveræne livsytringer involveret i en teologisk polemik om fordringen og dens indhold. Her kritiserede Løgstrup samtidens eksistensteologer for at gøre fordringen indholdsløs og hævdede i stedet, at fordringens indhold er kærligheden til det konkrete andet menneske. Fronten er imidlertid i en vis forstand den samme, nemlig ideen om, at det absolutte findes i det timelige, for når Løgstrup vil gøre medmennesket til fordringens indhold, er det udtryk for den opfattelse, at medmennesket kan absoluteres, uden at det idoliseres. Det er dermed skabelsestanken, der er katalysator også for denne polemik.

6. At Løgstrup udelader dette afsnit kunne skyldes, at han ikke vil ind i en diskussion om, hvorvidt det er en korrekt kritik af Kierkegaard og Sartre, men i stedet har villet sikre sig, at fokus lå på den vesentlige front, nemlig de suveræne livsytringer og dermed skabelsestankens betydning for eksistensen. 
Når Kierkegaard og Sartre overser denne 'normalitetens indesluttethed', overser de det ødelæggende i den helt almindelige indesluttethed; det medfører bl.a., at refleksionen hos Kierkegaard og Sartre fejlvurderes (jf. Løgstrup 1966, 36f). Som eksempler på almindelig indesluttethed, den indesluttethed som altså endnu ikke er blevet dxmonisk (de kredsende tanker og følelser), nævner Løgstrup fornarmelse, skinsyge og misundelse. Forskellen på den dæmoniske indesluttethed og normalitetens indesluttethed er ikke binær, men kontinuer - forskellen er i grad, ikke i art. Hvad dette betyder, ved alle, der har kendt forskellen på almindelig bekymring over for angst; på nedtrykthed over for depression; på en almindelig optagethed af sit arbejde over for den optagethed, hvor man ikke kan sove, fordi arbejdet trænger sig på, osv. Den dæmoniske indesluttethed er en potensering af de tanker og følelser, vi til daglig vikler os ind $\mathrm{i}-$ en potensering, der bliver så dominerende, at den holder os fast, så denne ene indesluttethed tager monopol på vores bevidsthedsliv i en grad, hvor de andre (normalt indesluttende) tanker og følelser overskygges af den, og vi ikke kan rive os ud af den.

I det følgende vil vi se nærmere på de væsentligste karakteristika ved de kredsende tanker og følelser.

\section{Indesluttende og vore egne}

Et hovedtræk ved de kredsende tanker og følelser er, at de er indesluttende: "Holdt i jegets snor, under dets pisk, går tankerne rundt og rundt i jegets egen manege". I I sit had, i sin bekymring eller jalousi er vi indesluttede i os selv: Vi ankommer til et sted uden at huske, hvordan vi kom dertil; vi glemmer at lytte efter, hvad der siges. Løgstrup peger på en lighed med lidelsen, som også er indesluttende: I lidelsen er den lidende ladt alene i isolation; det indre fiktive rum er forsnævret omkring én selv. Alligevel er lidelse noget andet end de kredsende tanker og følelser. Lidelsen er et fangenskab, men indesluttetheden

(...) bliver til af kredsende tankefølelser, had, sentimentalitet, selvretfærdighed. (...). Indesluttetheden er et fangenskab, som individet selv har indrettet sig, på een gang fange og fangevogter. Imaginært det hele, men lige livsødelæggende for det. ${ }^{8}$

Hvor det i lidelsen er

7. K.E. Løgstrup, Opgør med Kierkegaard (København: Gyldendal 1968), 94.

8. K.E. Løgstrup, Skabelse og tilintetgørelse (København: Gyldendal 1978), 186. 
(...) en fremmed magt, der lukker individet ude fra omgivelserne, fra de nærmeste, fra alt hvad der er til i rummet, fra tingene, landskabet, himmelhvælvet, horisonten og havet (,) (Løgstrup 1978, 186)

er det i de kredsende tanker og følelser os selv, der lukker os inde.

De kredsende tanker og følelser er som sådan vores egne indesluttende og selvkredsende tanker og følelser. ${ }^{9}$ Det er dem, vi er udleveret til, når vi er overladt til os selv. I denne forbindelse taler Løgstrup om det fiktive rum som udtryk for, at vores perspektiv indsnævres i indesluttetheden. I rumforsnavringen, som er fremkaldt og forårsaget af vores egne tanker og følelser, mister vi omverdenen og medmennesket af syne og kan til sidst, når indesluttetheden virkelig er blevet dæmonisk, kun se os selv; vi bliver rumløse (Løgstrup 1978, 40). Overladt til os selv er vi udleveret til os selv uden mulighed for at undslippe. Denne tilstand omtaler Løgstrup som ren and:

Den måske stærkeste tendens i vor tilværelse er tendensen til at være ren og skær ånd. Til at leve i et usynligt følelses- og tankerum, der kun giver ekko af sig selv. Det lyder uhyggeligt, men hvad andet er det, vi kalder selvoptagethed og selvkredsning og alle dens sentiments, had, skinsyge, misundelse, hævngerrighed.(Løgstrup 1978, 43).

Hvorfor er det den "måske stærkeste kraft i vores tilværelse"? Fordi det er vort selvs selviske kraft: det selv, der "(...) tager alt i sin selviskheds magt" ${ }^{10}$ Alligevel må vi spørge, om Løgstrup ikke her (som det også er sket andre steder) lader upræcisheden løbe af med sig, for med blikket på de suveræne livsytringer kan vi indvende, at det suveræne ved livsytringerne jo er, at deres magt på dette punkt er større end selvets selvindesluttende magt.

Hadet, skinsygen, misundelsen og hævngerrigheden omtales i citatet som selvoptagethedens og selviskhedens sentiments. De "(..) kommer af og udvirker sig i rumforsnævring” (Løgstrup 1978, 40), og rumforsnævringen bevirkes af selvets selviske, selvkredsende kraft, der danner dets egne følelser. Vores tanker og vores folelser dannes af os selv, hvilket vil sige, at de udkastes af selvet og derfor allerede er selviske. Dermed kan de også karakteriseres som kulturelle, ${ }^{11}$ om end vi skal huske, at Løgstrup ikke var kulturfjendtlig, og at denne be-

9. For en mere omfattende argumentation for, at de kredsende tanker og følelser er vores egne, og derfor ikke sensu strictu er livsytringer, se Rabjerg (2014), især 192-196.

10. K.E. Løgstrup, Den etiske fordring (København: Gyldendal 1956), 161.

11. Jf. Niels Thomassen, Filosofisk impressionisme. Temaer i K.E. Løgstrups filosofi

(København: Gyldendal 1992), 207. 
stemmelse derfor ikke $i$ sig selv er videre oplysende. Teologisk set er de et udslag af syndefaldet, hvor mennesket (idet det falder ud af sin oprindelige skabthed) bliver selvbevidst og dermed egoistisk. ${ }^{12}$ De er selve udtrykket for vores selvhævdelse, ikke kun (hvad Niels Thomassen skriver) "(...) led i selvhævdelsen (...)" (Thomassen 1992, 208), for selvhævdelsen er restløst udtømt i vores tanker og følelser.

Da tankerne og følelserne altid er vores, er det afgørende for forståelsen af Løgstrups mening med dem, at de ikke bliver hypostaserede eller reificerede, hvad de ellers ofte gør i Løgstrup-litteraturen, når man ser redegørelser for tankefølelserne, som var der tale om en ontologisk selvstændig (ydre) størrelse. De kredsende tanker og følelser er intet i sig selv - der findes ikke (antager jeg!) frit svævende tanker og følelser 'derude', som kan besætte mig. De kredsende tanker og følelser er altid mine tanker og følelser. De er ontologisk forankret $i$ mig; det er der, de hører til; det er mig, de stammer fra; mig der skaber dem. Derfor er de mit ansvar, og hvis jeg fralægger mig det, efterlades jeg i en skyldløshed, hvor jeg ifølge Løgstrup bliver til ingen (Løgstrup 1956, 190).

\section{Destruktive}

På grund af indesluttetheden er de kredsende tanker og følelser destruktive, hvilket vil sige, at de er livsnedbrydende eller livsforfalskende: De nedbryder det egentlige, skabte liv (som er tilgængeligt i de suveræne livsytringer, jf. nedenfor) ved at 'skygge for det', leve på bekostning af det og ved at omdanne det egentlige, som er skænket og åbnende, til noget selvisk, selvgjort og indesluttende. Ligesom når Løgstrup betegner mistilliden som tillidens deficiente modus (Løgstrup 1956, 28), er vores kredsende tanker og følelser en nedbrydelse af det oprindelige - beslægtet med hvad Løgstrup i sin disputats kalder "(...) en Skabelse i Afmagt", ${ }^{13}$ men hvor det i disputatsen gælder for erkendelsen, kommer det for den mere erkendelsesoptimistiske ældre Løgstrup til at dække over en etisk kategori: Vores egne tanker og følelser er moralsk set allerede korrumperede og korrumperende.

Én måde, hvorpå de nedbryder, er ved at forfalske forståelsen af, at livet er skænket mig, så jeg i stedet opfatter mig selv som mit eget ophav og derfor forstår det, der er mig skænket, som min fortjeneste. I mine selvkredsende tanker og følelser gør jeg det, jeg ikke er ophav til, til min ret eller retmæssige ejendom. Dette kender vi f.eks. fra, når vi i stedet for at tage kærligheden som givet, tager den for givet;

12. Jf. Ole Jensen, Historien om K.E. Løgstrup (København: Anis 2007), 111f, 115ff og $119 \mathrm{ff}$.

13. K.E. Løgstrup, Den erkendelsesteoretiske konflikt mellem den transcendentalfilosofiske idealisme og teologien (København: Samlerens Forlag 1942), 80. 
fra at forstå kærligheden som en ufortjent lykke (Løgstrup 1956, 147) opfattes den som fortjent: "Det er kun ret og rimeligt, at min datter elsker mig, når man tænker på, hvor meget jeg har gjort for hende"! Hvor destruktiv en sådan (kredsende) tankegang er, ser vi tydeligere, når den udtrykkes, men denne rethaveriske kærlighed lever antageligvis også bedst i skjul.

\section{Reaktive}

Et fællestræk ved vores kredsende tanker og følelser er, at vi i dem ofte (måske altid) overtræder billedforbuddet. Vi danner os billeder af den anden, af livet, af skæbnen (hvis vi føler, at livet går os imod), af os selv osv. Det destruktive i billeddannelsen består i det vrangbillede, som forestillingen kommer til at udgøre, fordi den i billeddannelsen fortegner livet og derefter skygger for det. Billedgørelsen er udtryk for en fremmedgørelse (Thomassen 1992, 208).

Billeddannelsen afslører, at vores kredsende tanker og følelser er reaktive: De opstår som reaktion på og følge af noget andet og mere oprindeligt. Som udtryk for vores selvcentrerede væren er mennesket i sine kredsende tanker og følelser reaktivt, da vi ikke kommer begivenhederne i forkøbet. Når vores tanker og følelser kredser, reagerer vi på de begivenheder, som finder sted (jf. Løgstrup 1966, 36).

Det er blevet indvendt mod Løgstrup, at det er uholdbart at hævde, at alt menneskeligt ressentiment er reaktivt. Denne indvending kommer imidlertid ikke nødvendigvis Løgstrup på tværs, for så vigtigt er det ikke for ham at fastlægge vores tanke- og følelsesliv som reaktivt. Det væsentlige er, at selv hvis vi af os selv, spontant, afføder ressentiment, så er det stadig et produkt af vores selvoptagethed eller selvkredsende virksomhed - ikke en direkte forholden sig til omverdenen.

\section{Spontane}

Dette leder over til det sidste vigtige træk: De kredsende tanker og følelser er spontane, da de kommer os selv i forkøbet. ${ }^{14}$ Dette kan lede til forvirring, for hvis de er udslag af os selv, hvordan kan de så komme før os selv? Her skal vi imidlertid huske på, at bestemmelsen af dem som vores egne er en metafysisk bestemmelse (Løgstrup 1956, 160). Men når Løgstrup siger, at "(...) vi (kommer) bagefter vore impulser (...)" (Løgstrup 1996, 26), er det en fanomenologisk iagttagelse. Der er altså ikke tale om en selvmodsigelse, selvom vi selvfølgelig her står over for spørgsmålet, hvorfor vi skal antage den metafysiske bestemmelse - især hvis den strider mod den fænomenologiske iagt-

14. K.E. Løgstrup, Etiske begreber og problemer (København: Gyldendal 1996), 26. 
tagelse? Derfor er der heller ikke en modsigelse mellem spontaniteten og reaktiviteten, for som reaktive eller ressentimentsforanledigede kommer vore kredsende tanker og følelser fænomenologisk set spontant bag på os på den måde, at det ikke er op til vores vilje, om de melder sig eller ej.

En anden grund til forvirring er, at også de suverene livsytringer er spontane, og at det er en udbredt praksis at omtale dem som spontane livsytringer - også (hovedsageligt senere i forfatterskabet) hos Løgstrup selv. Denne praksis er uheldig, da spontaniteten ikke er et differentierende kendetegn, hvorimod suveræniteten er det.

\section{De suveræne livsytringer}

Til en vis grad giver Løgstrup altså Kierkegaard og Sartre ret: Mennesket er i sine tanker og følelser selvisk. Imidlertid indvender han mod dem, at de med deres abstrakte tænkning (Kierkegaards abstrakte religiøsitet og Sartres abstrakte etik) placerer sig i en position, hvor de overser en væsentlig del af menneskets tilværelse (Løgstrup 1966, 34). Med abstraktionen væk fra tilværelsen afskærer de sig både fra den fulde forståelse af indesluttetheden samt fra de livsmuligheder, som kan bryde den. Dermed bliver de blinde for, at tilværelsen kan rumme absolut værdi. I artiklen fra 1966 fremhæver Løgstrup tilliden og barmhjertigheden som eksempler på suverane livsytringer - de samme som han i "Kristendom uden skabelsestro" fra 1962 brugte som eksempler på skabte livsmuligheder. ${ }^{15}$ Udgangspunktet var, at hvis tilværelsen er skabt, må den rumme tegn på dette. Livsytringerne er netop disse tegn. De er livs-ytringer: fremkomster af livet selv, og livet er det skabte, mellem-menneskelige liv. Disse livsytringer sikrer og muliggør, at livet ikke strander på menneskets indesluttende og selviske tanker og følelser - uden dem ville tendensen til at blive ren and vinde:

Når det alligevel ikke går så uhyggeligt til, når den tendens ikke sejrer, skyldes det alle tings legemlighed, som vi, selv legemlige, er indlemmet i. Uafbrudt opløses ekkorummet af legemligheden, der i sansningen strømmer ind til os. Ondskab er ånd uden legem. Ondskaben er tilintetgørende magt, og det er legemligheden, der skal tilintetgøres.

15. K.E. Løgstrup, “Kristendom uden skabelsestro”, Vindrosen 9 (1962), 523-535. 
Hvert øjeblik vi lever oplades vort sind af den legemlighed, som vi er indfældet i. Den stemmer vort sind, tilfører det al oplagthed, også den oplagthed der skal til for at hade, være forurettede og lægge øde. Endog destruktionen af andres livsmuligheder og selvdestruktionen kommer i stand ved den stemte oplagthed, hvormed legemligheden ved alt hvad der er til velsigner vort liv, for nu at bruge et gammeldags og religiøst ord (Løgstrup 1978, 43).

Tilliden, barmhjertigheden, talens åbenhed osv. er konkrete manifestationer eller ytringer af livet selv, og som sådan har også de suverene livsytringer en række karakteristika, som vi skal forsøge at afklare:

\section{Definitive}

Et centralt træk ved livsytringerne er, at de er udtryk for noget ferdigt, noget skabt, heri ligger deres definitivitet. ${ }^{16}$ Dette skyldes, at livsytringerne ytrer "(d)et bestemte, vort Menneskeliv er som skabt (...)" (Løgstrup (1942), 91, jf. 86). Livsytringerne må forstås som havende en bestemt karakter, og de kan ikke være eller forstås på andre måder end denne. At give noget med en bagtanke er ikke at give, men at tage eller købe. At give eller at vise barmhjertighed er udtryk for en helhed, som ikke lader sig ændre, uden at den helt forandres og slår over i sin modsætning: Give bliver til tage, barmhjertighed bliver til manipulation eller egennytte. Caroline Schaffalitzky de Muckadell foreslår en sondring mellem bestemtheds-definitivitet som udtryk for, at livsytringerne altid skal forstås som havende et bestemt (deskriptivt) indhold, og moralsk definitivitet, nemlig at livsytringerne har en bestemt axiologisk kvalitet i form af en moralsk værdiladning som enten god eller ond. ${ }^{17}$ Denne sondring er imidlertid problematisk. For det første overser den, at den såkaldte moralske definitivitet allerede er indeholdt i bestemtheds-definitiviteten: Det bestemte, som livsytringen er, er ikke kun det deskriptive indhold, men også den axiologiske værdiladning; man kan således ikke skelne mellem barmhjertigheden eller det at give som et deskriptivt fænomen (altså en handlings bestemte deskriptivt ekspliciterbare dynamik) og fænomenets axiologiske ladning som et godt fænomen. Dynamikken og værdien konsti-

16. Mogens Pahuus kritiserer den forestilling, at definitiviteten forudsætter skabelsestanken (Mogens Pahuus, "Suveræne livsytringer. Filosofisk analyse og religiøs tydning”, Studenterkredsen 2-3 (1972), 17-22). Løgstrup modsætter sig indvendingen, fordi skabelsestanken hos ham er en forudsætning for definitiviteten ("Svar til Mogens Pahuus”, samme sted). Pahuus' indvending kan derfor bruges til at skitsere et alternativ til Løgstrup, men ikke som en udlægning af ham, hvorfor definitiviteten $i$ Logstrups udformning er udtryk for, at livsytringerne er skabt.

17. Caroline Schaffalitzky de Muckadell, Løgstrups etik (København: Gyldendal 1997), $18 f$. 
tuerer fænomenet. Et andet problem med den foreslåede sondring er, at den med opstillingen af muligheden for, at en livsytring kan være både god og ond, går ud fra, at de kredsende tanker og følelser også er at forstå som en art livsytringer, nemlig negative livsytringer, men denne misforståelse er allerede imødegået (Rabjerg 2014, 178-196).

\section{Fuldbyrdede}

Som skabte er livsytringerne at forstå som noget, der reelt eksisterer som ontologiske træk ved tilværelsen; de må forstås som realiserede eller fuldbyrdede. Ole Jensen gør i en i Løgstrup-forskningen særdeles kendt artikel opmærksom på, at der er en tvetydighed hos Løgstrup i tiden op til Opgør med Kierkegaard. ${ }^{18}$ I Den etiske fordring accepterer Løgstrup nogle steder, at vi må forstå tilliden og den naturlige kærlighed som tænkte størrelser, da vi kun kender dem i den selviske skikkelse, vi har givet dem i vort liv (Jf. Løgstrup 1956, 158). Når jeg kun kender tillid og kærlighed som hhv. min tillid og min kærlighed, er der i abstraktionen tillid og karlighed som absolutte størrelser tale om en idealiserende hypostasering. Tilliden og den naturlige kærlighed manifesterer sig altså angiveligt ikke som ikke-egoistiske fænomener; de fuldbyrdes ikke, som Ole Jensen skriver. Men samtidig kan han påpege, at i starten af Den etiske fordring taler Løgstrup netop om tilliden som en kendsgerning, der melder sig i ethvert møde mellem mennesker, og at det er den manglende fuldbyrdelse, der bringer fordringen frem. Denne tvetydighed ligger i Løgstrups tænkning i de næste ti år, indtil han må tage konsekvensen, hvilket sker med de suveræne livsytringer.

De suveræne livsytringer er fuldbyrdede, da de 'bærer' vores liv, så det ikke prisgives indesluttetheden. Når tilliden bliver en suveræn livsytring, medfører det altså en korrektion af de tanker i Den etiske fordring, hvor Løgstrup lader synden og menneskets magt blive så omfattende, at de helt forhindrer tilliden og den naturlige kærlighed (altså livsytringerne) i at melde sig. Man kan sige, at Løgstrup ender med at tage konsekvensen af det, han i Den etiske fordring negativt kaldte for hypostaseringen, for livsytringerne er en form for ontologisering af tilliden: Han betoner, at de som fuldbyrdede har ontologisk status som eksisterende træk i tilværelsen.

\section{Suverane}

At livsytringerne er suveræne griber tilbage til den magtbestemmelse, vi finder af livsmulighederne i 1962: De formår at trænge igennem

18. Ole Jensen, “'Skabte livsmuligheder' - 'Suveræne livsytringer”, Sårbar usårlighed. Logstrup og religionens genkomst i filosofien (København: Gyldendal 1994), $18-34$. 
vores indesluttethed i egoismen, om end denne suverænitet ikke betyder, at de altid sejrer; det formår de højst i momenter. På samme måde betyder bestemmelsen af livsytringerne som fuldbyrdede ikke, at de altid nødvendigvis lykkes. At livsytringerne melder sig, kan vi intet stille op imod; som sådan er de et uudryddeligt træk ved tilværelsen. Noget andet er, at når de har meldt sig, kan de ødelægges af os. At tilliden melder sig i det interdependente liv, at den kommer til syne eller opstår i situationen, er ikke mit værk. Men når den har vist sig, er det i min magt at fortrænge den eller misbruge den. Deri består livsytringens skrøbelighed, hvilket er en følge af dens skabthed (Løgstrup 1962, 529f).

Der ligger i suverænitetsbestemmelsen en tvetydighed, som fremhæves af Lars-Olle Armgard ${ }^{19}$ og ekspliciteres af Schaffalitzky (Schaffalitzky 1997, 17f) med sondringen mellem gennembrydnings-suverenitet og selvrealiserings-suvercnitet. Det første er udtryk for, at livsytringernes suverænitet består i, at de ikke kan forhindres i at melde sig, mens det sidste er udtryk for, at de, når de melder sig, melder sig med et krav om overtagelse af situationen - et krav, vi godt nok kan overhøre eller pervertere, men som ikke desto mindre er til stede.

Denne udlægning af suveræniteten er imidlertid ikke helt problemfri. Der kan ikke være tvivl om, at Løgstrup i en periode indtil kort efter 1972 har ment, at suveræniteten bl.a. bestod i, at vi ikke kunne forhindre livsytringen i at melde sig: Suveræniteten implicerede gennembrydnings-suverænitet, og en konsekvens af denne var, at livsytringerne var ubetingede. Det ser vi f.eks. i følgende citat:

\section{Det besynderlige er, at på trods af og tværs igennem vor uudryddelige indbildning baner livsytringerne sig vej (...). Så suveræne er de, at ind- bildningen ikke kan hindre dem $\mathrm{i}$ at bryde igennem. ${ }^{20}$}

Der kan imidlertid heller ikke være tvivl om, at Løgstrup senere justerer denne opfattelse. I hvert fald skriver han i Ophav og omgivelse, at tilliden godt nok ingen indre betingelser har - den snylter ikke på og er ikke afhængig af andre fænomener for at opstå -, men den har til gengæld ydre betingelser for, om den kommer til udfoldelse eller ej - vi kan kalde dem realiseringsbetingelser:

19. Lars-Olle Armgard, Antropologi. Problem i K.E. Lögstrups författarskap (Lund: Gleerups 1971), $46 \mathrm{f}$.

20. K.E. Løgstrup, "Eksistensteologisk og religionsfilosofisk tolkning af Jesu forkyndelse" (Upubliceret), 33 sider (2). Uddrag af manuskriptet er blevet trykt under samme titel i Studenterkredsen 39 (1971), 55-63. 
Men tilliden har ydre betingelser, i forældrenes opførsel i hjemmet og samfundet, i barnets temperament og karakter. (...) For tillidens vedkommende giver de ydre betingelser den gode eller dårlige vilkår. De enten udløser tilliden og giver den gode vækstvilkår, eller de fortrædiger den i selve dens udspring og giver den dårlige vækstvilkår. Men de ydre betingelser skaber den ikke. Ikke tilliden selv, kun dens skæbne i den enkeltes tilværelse er et resultat af de ydre betingelser. ${ }^{21}$

Niels Thomassen påpeger, at det er svært at se, hvorfor barnets temperament og karakter henregnes til de $y d r e$ betingelser for tilliden (Thomassen 1992, 202). Synsvinklen er imidlertid her anlagt fra tillidens side og ikke fra barnets. For tilliden som ontologisk real størrelse er barnets temperament, tonen i hjemmet (i form af travlhed, åbenhjertighed, kærlighed osv.) netop ydre betingelser. Disse er afgørende for, om tilliden får anledning til at bryde frem i den enkeltes liv. Det betyder imidlertid ikke, at tilliden ophører med at være suveræn, for realiserings-suveræniteten bevarer den i den forstand, at den, når den melder sig, melder sig som en vilje til at sætte situationen i skred for at forårsage en handling. Løgstrup har modificeret gennembrydningssuveræniteten på den måde, at han har fået øje på, at et menneske kan være mere eller mindre åbent overfor verden, og at en ekstrem lukkethed i egocentri eller refleksion kan forhindre, at livsytringerne melder sig. Måske kan man ikke forhindre dem helt; man kan f.eks. næppe i alle situationer modstå den andens ban (jf. Løgstrup 1956, 23), den gennembrydningskraft som ligger i tilliden i mødet med det andet menneske, men en generel lukkethed overfor omverdenen kan nedsætte frekvensen af livsytringernes opstån i ens liv, og dermed har vi en magt over dem. Måske kan f.eks. omfattende traumatisering i tidlig barndom og fremefter føre til, at livsytringerne ikke kan bryde igennem.

\section{Spontane}

Af deres suverænitet ser man også livsytringernes spontanitet. De opstår umiddelbart af situationen, og melder sig så pludseligt, at de kommer bag på os. ${ }^{22}$ Spontaniteten betyder derfor, at der aldrig kan være en skjult dagsorden i forbindelse med livsytringen (Løgstrup 1972, 18f). Når livsytringen opstår, gør den det uden bagtanker. Sin motivering kan den kun hente fra anledningen til sin opståen: "Om den suveræne livsytring gælder det (...), at den er motiveret af det tilsigtede handlingsresultat. Sindelag og hensigt kan ikke skilles ad"

21. K.E. Løgstrup, Ophav og omgivelse (København: Gyldendal 1984), 175.

22. K.E. Løgstrup, Norm og spontaneitet (København: Gyldendal 1972), 17. 
(Løgstrup 1972, 26). Der er ingen afstand fra sindelaget til handlingens mål - livsytringen er altid en tilskyndelse til noget, og dette noget er livsytringens indhold. Hvis livsytringen ikke gennem handlingsforløbet bevarer sin spontanitet, slår den om i sin modsætning:

Spontaneiteten er ikke noget, der kan være mer eller mindre af, den må være alt, hvis den suveræne livsytring overhovedet skal bestå. Radikaliteten består ikke i noget mesterligt, men i at den mindste bagtanke er udelukket.(Løgstrup 1972, 19).

Spontaniteten skal forstås som et binært begreb: Enten er den spontan i sin absolutte form, eller også er den det overhovedet ikke. Her ligner spontanitetsbestemmelsen definitiviteten.

Som vi så, er også de kredsende tanker og følelser spontane. Derfor er det væsentligt at understrege, at spontaniteten er af forskellig art: Begge typer af fænomener, er fænomenologisk set spontane, men de kredsende tanker og følelsers spontanitet er affødt af ressentiment, hvilket indebærer, at de metafysisk set har os selv som ophav. De suveræne livsytringers spontanitet derimod skal forstås som umiddelbart spontane manifestationer af det skabte, interdependente liv. ${ }^{23}$

\section{Ubetingede}

Når der ikke går noget forud for livsytringen, når den opstår spontant af situationen, følger det også, at den er begrundelsesmæssigt ubetinget: ${ }^{24}$

Af den grund forbyder de spontane livsytringer al retfærdiggørelse. I samme øjeblik vi søger at begrunde dem, gør vi dem betingede af det som vi begrunder dem med, og de er på stedet fordærvede. Vi har gjort dem til middel for et andet formål end deres eget, nemlig til middel for det formål der er til stede i retfærdiggørelsen. ${ }^{25}$

Heri ligger også, at livsytringerne ikke er rationaliserbare, da de ligger til grund for rationaliseringen. Som sådan er de mulighedsbetingelser for begrundelse og rationalisering - livsytringerne er prøvesten for rationalisering: "Tilsammen udgør de ikke-rationaliserbare livsytringer

23. Løgstrups inddeling her kan virke postulatorisk, men den er ikke ad hoc, da den hviler på den tydning af ontologien, som skabelsestanken indebærer. Jf. Rabjerg (2014), 180-188.

24. Bemærk, at der her tales om begrundelsesmassig ubetingethed. Denne medfører ikke en modifikation af det tidligere nævnte forhold, at livsytringerne har ydre betingelser, da disse er realiseringsbetingelser.

25. K.E. Løgstrup, System og symbol (København: Gyldendal 1982), 107. 
det fundament som vor rationalitet bygger på” (Løgstrup 1982, 119). De handlinger, som udspringer af livsytringernes tilskyndelse, kan derfor ikke begrundes i selve livsytringen. Skal en handling begrundes, må dette ske under henvisning til den situation, som handlingen udsprang af. På baggrund af situationer og handlinger kan man formulere normer, men samtidig må man gøre sig klart, at normerne dermed hverken er formuleringer eller begrundelser af livsytringerne.

Givet at livsytringerne indtager en så privilegeret og oprindelig position, at de unddrager sig rationel begrundelse, må en suspension af livsytringerne derfor altid kræve en begrundelse. Suspensionen af livsytringerne må ses som en bevidst handling, og som det fremgår, kan handlinger altid afkræves en begrundelse ud fra den konkrete situation, som handlingen opstod af (Løgstrup 1982, 111).

\section{Identitetsskabende}

Livsytringernes suverænitet medfører, at de er identitetsskabende. Da de sætter en grænse for vores egocentri og har magten til at overtage os, så vi glemmer os selv (eller glemmer at tænke på os selv først), har de magten til, at vi, når vi overtages af dem, handler fri fra synd altså fri fra vores selviske indesluttethed. Igennem livsytringerne ser vi, hvem vi egentlig er, eller hvem vi ville være, hvis ikke indesluttetheden havde indtruffet. Her ses en klar imødegåelse af Kierkegaards forestilling om, at det kun er i refleksionen, at den enkelte kan blive sig selv. For Løgstrup at se til bliver vi aldrig os selv i refleksionen; kun når vi glemmer os selv, er vi os selv.

\section{Anonyme}

En sidste bestemmelse skal fremhæves: Livsytringerne er anonyme. Spørgsmålet er her, hvilken ontologisk status livsytringerne har, og samtidig må vi rette spørgsmålet til de kredsende tanker og følelser: spørgsmålet om den ontologiske differens mellem de suveræne livsytringer og de kredsende tanker og følelser. ${ }^{26}$

Når Løgstrup bestemmer de suveræne livsytringer som både anonyme og vores, skyldes det, at de til forskel fra de kredsende tanker og følelser, som kun er vores, også er noget andet. Som Ole Jensen skriver: "de stammer ikke fra os, men fra tilværelsen, selvom de samtidig kommer til udtryk i os som personer, og: de er der, hvad enten vi vil vide af det eller ej" (Jensen 2007, 170f). De er mellem-menneskelige strukturer, som griber ind i vores liv og bringer os i berøring med tilværelsen. Anderledes med de kredsende tanker og følelser. De er ikke

26. For en mere omfattende analyse af denne ontologiske differens i Løgstrups forfatterskab henvises til Rabjerg (2014). 
livsytringer: De er ikke udtryk for det skabte liv, men er vores skyld og frembringelser. Hvis de endelig skal betegnes som ytringer, er de menneskeytringer (ytringer af selvet). Derfor har en livsytring heller ikke en variabel moralsk definitivitet (jf. ovenfor), der bestemmes som enten god eller ond, selvom Løgstrup undtagelsesvis kommer til at udtrykke det på den måde. Som livsytring kan den kun være god. De kredsende tanker og følelser må derimod bestemmes som onde. ${ }^{27}$

Hvor de kredsende tanker og følelser er kulturelle, er de suveræne livsytringer før-kulturelle. Vi har en magt over dem, men den er ikke ubegrænset: "Til den grad er de vore, at vi kan ødelægge dem. Til den grad er de anonyme, at vi kun kan ødelægge dem til vor egen ødelæggelse" (Løgstrup 1982, 141). Som en del af skaberværket kan de gribe ind i vores tilværelse, og som skabte korresponderer vi med skaberværket gennem dets strukturer (livsytringerne). At vi er skabte betyder, at livsytringerne kan finde tilknytning og anledning i vores eksistens.

Ud fra disse betragtninger kan man være både enig og uenig $\mathrm{i}$ Schaffalitzkys overvejelser omkring Løgstrups såkaldte tvedeling af selvet: "Både de suveræne livsytringer og de kredsende tankefølelser er en del af menneskets natur" (Schaffalitzky 1997, 20), skriver hun og påpeger, at der er den forskel, at kun de sidste skyldes os selv. Herefter konkluderer hun:
Dvs. der er altså tale om en slags tvedeling af selvet i 'det skænkede' og 'det ikke-skænkede'. Mens de suveræne livsytringer altså er en del af den menneskelige natur, er de kredsende tankefølelser individuelle skavanker (Schaffalitzky 1997, 20).

27. Både Thomassen og Pahuus retter relevante indvendinger mod Løgstrup, men da det følger af Løgstrups antropologi, at mennesket af ham forstås som gennemgribende syndigt, kan man ikke komme udenom, at de kredsende tanker og følelser må forstås som onde. Noget andet er, at man kan anfægte denne antropologi, blot ophører det så med at være Løgstrups. Derfor er vi for Løgstrups vedkommende nødt til at fastholde den meget skarpe sondring mellem kredsende tanker og følelser på den ene side og suveræne livsytringer på den anden. Thomassen har efter alt at dømme ret i sin indvending mod Armgard, at de kredsende tanker og følelser må ses som onde (Thomassen 1992, 255). Men Armgards udgangspunkt er nok, at de kredsende tanker og følelser ikke lever op til at være definitive i den fulde betydning, bl.a. fordi de ikke er skabte og altså ikke er givne (dette har Armgard tilsyneladende blik for, selvom han stort set konsekvent omtaler de kredsende tanker og følelser som kredsende eller negative livsytringer og dermed terminologisk hypostaserer dem). Ud fra denne betragtning har de begge ret: De kredsende tanker og følelser må ses som onde, men da den axiologiske ladning ikke udtømmer definitiviteten (definitivitet er mere end moralsk definitivitet, jf. ovenfor), har Armgard ret i, at de ikke er definitive; jf. Armgard (1971), 49. 
Det er korrekt, at de suveræne livsytringer i en vis forstand er vores, og de kredsende tanker og følelser er det også. Når hun kalder de kredsende tanker og følelser for "individuelle skavanker", viser hun imidlertid, at hun hverken har blik for indesluttethedens omfang eller for dens radikalitet. Den manglende forståelse finder vi igen senere i bogen for livsytringernes vedkommende. De er nemlig ikke kun en del af den menneskelige natur, hvad Schaffalitzky lader til at mene, men går i en helt væsentlig forstand vores natur imod - det er derfor den kærlighed, som fordringen fordrer, brydes af menneskets natur, for menneskets natur er ikke at elske andre, men at elske sig selv og sit (jf. Løgstrup 1956, 124f.). Derfor er en præcisering på sin plads: Menneskets sind er tvedelt eller dobbelt hos Løgstrup, da mennesket er skabt, men også selvforskyldt syndigt (indesluttet). Løgstrup forstår nemlig mennesket som så indesluttet, at de selviske motiver sætter sig igennem, med mindre de suspenderes af en stærkere kraft: de suveræne livsytringer. Derfor sætter livsytringerne en grænse for menneskets magtudøvelse: Hvis der ingen livsytringer var, ville mennesket have uindskrænket magt og ødelæggelseskraft. Vi ville være prisgivet ondskaben og egoismen. Men sådan forholder det sig ikke, for tilværelsen er skabt med suveræne livsytringer i sig, der på trods af vores vilje "sprænger indesluttetheden" (Løgstrup 1968, 112). Som perspektivåbnende og handlingstilskyndende er livsytringen suveræn. Det betyder, at mennesket har et egentligt jeg, som på grund af indesluttetheden (teologisk formuleret: synden) trænges tilbage. Formuleret mindre teologisk kunne man skelne mellem menneskets selvforglemmende åbenhed og dets selviske indesluttethed, hvor Løgstrup forstår åbenheden som vores egentlige jeg. Problemet er blot, at indesluttetheden er så stærk, at vores egentlige jeg kun kan slippe fri, når det forløses udefra gennem de suveræne livsytringer.

Hvor de kredsende tanker og følelser helt og holdent er udtryk for menneskets natur, de er ontologisk forankret i selvet (jf. ovenfor), opstår spørgsmålet, i hvilken forstand de suveræne livsytringer kan forstås som mine - og i hvilken forstand de ikke kan det; hvor er livsytringernes ontologiske forankring? Her ligger risikoen for en reifikation (eller hypostasering, som Løgstrup kalder det) på lur: Skal livsytringerne forstås som objektive værdier eller fænomener 'derude', og hvad betyder dette i så fald? Løgstrup giver aldrig et klart svar, hvilket er beklageligt, da det er et vigtigt punkt i hans metafysik og etik, og de ting, han siger, peger ofte i forskellig retning. James Mackie har rejst afgørende indvendinger mod forestillingen om objektive værdier ud fra det såkaldte argument from queerness: Enhver teori, der indeholder objektive værdier, må implicere en markelig (Mackie: que- 
er) metafysik. ${ }^{28}$ Løgstrups tanker om de suveræne livsytringer (men ikke de kredsende tanker og følelser, da de kun er vores) er sårbare for Mackies kritik, men via en præcisering og en fortolkning kan de holdes fri. Praciseringen omhandler etikkens ontologiske forankring i den skabte tilværelse: interdependensen. Det betyder, at det er via den anden (altså medmennesket), at livsytringerne 'bliver til'. Det afgørende er den positive konsekvens af interdepensen, at vi ikke er overladt til os selv, men at medmennesket med sit nærvær (sit ban) kan rive os ud af os selv, så vores indesluttethed brydes. ${ }^{29}$ Fortolkningen går ud på, at livsytringernes åbenhed konsekvent må fortolkes ikke som en åbenhed fra den enkelte ud til medmennesket, men i stedet som en åbenhed i vores indesluttethed, der foranlediges af medmennesket; retningen i intentionaliteten går godt nok fra selvet mod den anden, men åbenheden stammer fra medmennesket - ikke fra mig! Kun forstået på denne måde kan livsytringerne (barmhjertighed, talens åbenhed, tillid, kærlighed osv.) opfattes som skænket mig, og ikke som noget, jeg selv er ophav til. Det andet menneske forløser mig fra min indesluttethed, hvorved jeg sættes fri i selvforglemmelse. I den optagethed af den anden, som denne åbner i mit sind, sættes mit skabte jeg fri fra mit selviske selv. Denne indsigt har Løgstrup artikuleret i en journaloptegnelse fra 1930'erne - altså lang tid inden han begynder at udfolde tankerne: "Vi er fangne i os selv. Befris kan vi kun af vort medmenneske". ${ }^{30}$

Dette betyder, at livsytringerne er ontologisk forankret i medmennesket - ikke som noget dette selv kan ville mobilisere, men som en positiv konsekvens af interdependensen og dermed af den indvirkning på selvet, som medmennesket kan foranledige (om han eller hun vil det eller ej).

Afslutningsvis skal det påpeges, at livsytringerne (og dermed medmennesket) hos den sene Løgstrup ikke har monopol på at nedbryde indesluttetheden og at åbne mennesket, så det rives ud af sin indesluttethed. Som det fremgår af nogle af de anvendte citater fra Skabelse og tilintetgørelse, kan sansningen og dermed al tings legemlighed også gøre det: Rummets etik bliver for den sene Løgstrup den positive

28. James Mackie, Ethics. Inventing right and wrong (London: Penguin 1977).

29. Interdependensen fremstilles oftest negativt, idet den betegner den udleverethed vi lever $\mathrm{i}$, hvor vi risikerer at blive svigtet, skuffet eller på anden vis komme galt afsted i det mellem-menneskelige liv. At den positive konsekvens er overset er imidlertid overraskende, når man tænker på, hvor almindeligt det fænomen er, at ens indesluttethed ophæves af det andet menneskes indgriben eller nærvær; blot et smil kan være nok til, at indesluttetheden for et øjeblik suspenderes.

30. K.E. Løgstrup, Kollegiehæfte XXV.3.1 (uden år), 34. 
modvægt til rumforsnævringen og dermed til indesluttetheden. Med sansningen bliver det også tydeligt, at hvor livsytringerne hos den lidt yngre Løgstrup kunne ses som mere punktuelle undtagelser, der brød ind $\mathrm{i}$ indesluttetheden, bliver sansningen en voldsom udvidelse af disse indbrud i selvet. Dermed bliver indesluttetheden også stærkt begrænset hos den senere Løgstrup, mens den er nærmest altdominerende hos den tidligere. Dynamikken er den samme, nemlig at menneskets indesluttethed kun kan brydes udefra, men mulighederne for at bryde indesluttetheden er (især i kraft af sansningen) langt større hos den sene Løgstrup end hos den yngre. Menneskesynet bliver ikke mere positivt, men det gør synet på magtforholdet, hvorfor mennesket hos den sene Løgstrup bliver bedre hjulpet og dermed mere vedvarende forløst. 